\title{
Mapping the Ottoman Cyprus through Travellers' Eyes
}

\author{
Merve Senem Arkan ${ }^{\mathrm{a}}$ \\ ${ }^{a}$ Eastern Mediterranean University - m.senemarkan@ gmail.com
}

\begin{abstract}
Cyprus, the island that stands at the crossroads of three continents, was a customary visitation stop for many travellers. Numerous accounts by these travellers were able to capture the details of Ottoman Cyprus in their accounts as well as giving visual descriptions of the cities. During the transformation of the island as a part of the Ottoman Empire, these historical texts and images were helpful to determine the context and representation of the cities while depicting changes and adding new information throughout the 300 years of Ottoman rule. These depictions on maps, drawings, and sketches prepared by the foreign travellers who visited Cyprus during the earlier period of the Ottoman era - the seventeenth and eighteenth centuries - will be examined. The focus will be on the representations of major cities of Cyprus, namely Famagusta, Nicosia, and Larnaca, which travellers visited and wrote about frequently. In this paper, I will examine the parallels between text and depictions to see the travellers' awareness of what they witnessed and if they were able to reflect this in their images of Ottoman Cyprus. I will discuss the outsider's point of view towards the Ottoman Cypriot cities, as well as how they presented the Ottoman Empire and Cyprus to their audiences.
\end{abstract}

Keywords: Cypriot cartography, travel accounts, Ottoman Cyprus.

\section{Introduction}

Cyprus, the island that stands at the crossroads of three continents, was a customary visitation stop for many travellers. Numerous accounts by these travellers were able to capture the details of Ottoman Cyprus as well as give visual descriptions of the cities. These texts provide vital information about the context of the cities, namely their history, structure, administration, and economy amongst many other details. These sources are putting the texts and the cartographic representations in the spotlight to visualize Ottoman Cyprus.

The interest in the Ottoman Empire by foreign travellers caused the production of many travel texts and their translations in several languages which reached out to a large audience. These writings increased in production in the sixteenth century and continued in the seventeenth century, primarily created by French and later on by German and Dutch travellers (MacLean, 2019, p.65). These accounts were also accompanied by visuals as they became evidence of the travellers witnessing certain occurrences during their experiences in foreign lands (Leitch, 2019, p.456).

During the transformation of the island as a part of the Ottoman Empire, these historical texts and depictions are helpful to determine the context and representation of the cities while depicting changes and adding new information throughout the 300 years of Ottoman rule. In addition, these depictions through travellers' eyes have become significant visual sources to understand Ottoman Cyprus in times when the map production had decreased and the majority of the urban maps from this era were replicas of the sixteenth-century siege maps (Arkan, 2018). Furthermore, they were part of the circulation of data which provided information for the map makers who did not visit the island as they used these texts to construct their images.

In this paper, I will examine the parallels between text and depictions to see the travellers' awareness of what they witnessed and if they were able to reflect this in their images of Ottoman Cyprus. I will discuss the outsider's point of view towards the Ottoman Cypriot cities, as well as how they presented the Ottoman Empire and Cyprus to their audiences. The representations prepared by the foreign travellers who visited Cyprus during the Ottoman era between 1571 and 1878, focusing on the earlier period, i.e. the seventeenth and the eighteenth centuries, will be examined.

For this paper, among many travellers who visited the island, works of selected few according to their accessibility and relevance will be discussed. The images were chosen according to their makers; those who have a travel account on Cyprus that is accompanied by a map or a drawing or a sketch of one or more of the cities of Cyprus. As Preziosi (1991) explained "A city is never neutral: the urban fabric is a device for tracking, measuring, controlling, and predicting behaviours over space and time" (p.5), cities are always changing and adapting to their rulers and societies which makes them ideal to follow the travellers' point of view towards Ottoman Cyprus. The focus will be on the representations of the major Cypriot cities of Famagusta, Nicosia, and Larnaca which travellers visited and wrote about frequently. As the capital city, Nicosia was the seat of the 
governor, and in the port cities Famagusta and Larnaca the majority of commerce was carried out. Their images through the eyes of travellers will give us the outsiders' point of view towards Ottoman Cyprus and how the society and cities under Ottoman rule changed and adapted to their new rulers.

\section{Ottoman Cyprus: The Cities}

Cyprus is a multicultural island where the traces of the old and new rulers and the changes can be seen all over its land. The island was ruled by the Lusignan dynasty from 1192 until 1489 when the Venetians took over the island (Gunnis, 1947, pp.15-20). In 1570 the Ottoman Empire conquest started. Nicosia and Famagusta, two fortified cities were under siege during this conquest. The Ottomans first marched to Nicosia and took over the city within seven weeks (Hill, 1948, p.967), however, the siege of Famagusta lasted almost a year. When the Ottomans conquered the island in 1571 it was with the fall of Famagusta (Gunnis, 1947, p.85). Afterwards, significant changes occurred concerning the island's administration, culture, and religion.

During and after the conquest, the island suffered from a decreased population, as well as damages and neglect. To increase the population, the Ottoman Empire took several precautions (Gazioğlu, 2000, pp.148-149). For example, between 1573-74, the Ottoman Empire sent people and soldiers from Anatolia (Gürkan, 2006, p.35). This caused the population of the island to be separated into two main ethnic groups: the Greeks and the Turks.

The besieged cities were damaged during the conquest, especially Famagusta where many buildings were left unattended and left to decay. Cornelis de Bruyn wrote about the St. George of the Greeks in Famagusta when he visited the island in 1683. "On the left of it is another mosque whose dome makes it very conspicuous. One can see the holes left by the cannonballs: half the church was destroyed in the siege" (Cobham, 1908, p.236). In addition, the Christian population was forced out of the city after the conquest, they moved to the south of the city to "Varosha" (Jeffery, 1918, p.224). So only a small number of people stayed within the city walls as Mariti (1909) observes in 1760 as “... where in every street you meet only ruin and destruction... So deserted is the city that it contains but 200 souls" (p.65;67).

The situation was not as dire in Nicosia as it was in Famagusta. Nicosia continued to be the capital city, however, its population decreased and many buildings were left vacant. The heavy damage the city sustained during the war was still apparent and even the travellers observed and documented a bruised city in ruins rather than a lively and beautiful Mediterranean city. Girolamo S. J. Dandini wrote about the city when he visited it in 1596:
Nicosia is a large city and well built after the Oriental fashion. But in the last wars, it was destroyed in several places. For it is now twentyseven years since the Turks took the city from the Venetians... The towers or belfries are ruined, or without bells, which the Turks have turned into pieces of ordnance (Cobham, 1908, p.181).

Religion caused a major transformation in these cities. Islam became the official religion after the Ottoman conquest, while previously Cyprus had been a Christian island, with various ethnic groups (Luke, 1969, p.13). Reconstruction and repurposing of old buildings, as well as new and oriental-styled ones, can be seen within the cities. With the increasing population of the Turks, the changes in structure, daily life, and culture could be observed all around (Gürkan, 2006, pp.35-36). Symbolically, this transformation was epitomized in Famagusta with the conversion of St. Nicholas Cathedral into the Lala Mustafa Pasha Mosque. In Nicosia, St. Sophia Cathedral was converted to Selimiye Mosque, on which minarets were added to the Lusignan architecture. The pointed top of these minarets and crescents (Rüstem, 2019) became the symbol of Ottoman rule on the depictions.

During the process of transformation of Famagusta, new constructions serving the Ottoman culture were started. Several bathhouses (hamam) and schools (medrese) were built within the walled city. For instance, in the main square, beside the Palace, the Cafer Paşa fountain and baths were constructed. Also, near the Cathedral and close to the land gate Akkule Mescit (mosque) a school was built (Uluca, 2006, pp.139-143).

In this era, Nicosia became a city that tried to renovate itself and created a common ground for its multicultural population. With these innovations, the city had a new look; a mixture of Christian and Muslim cultures and designs where the lower part is in Gothic style and the upper part was in the Ottoman style with cumba (bay windows, balconies) and new Ottoman-style buildings like mosques, mausoleums (türbe), khans, bathhouses and houses with cumba, and fountains that rose throughout the city within its narrow and irregular streets (Gürkan, 2006, pp. 33-35). The famous Büyük Han (the Great Khan), one of the most important Ottoman monuments in Nicosia, was built after the conquest and it served as an inn for travellers. In several accounts, the beauty of the city, as well as the gardens, were emphasized. J. Sibthorm who was a professor of Oxford University examined the flora and fauna of Cyprus and wrote about the city's changed appearance in 1787:

The flat roofs, trellised windows, and light balconies of the better order of houses, situated as they are in the midst of gardens of oranges and lemons, give together with the fortifications, a respectable and picturesque appearance to Lefkosia at a little distance (Cobham, 1908, p.339). 
Larnaca was a developing town which travellers often mentioned together with Salines where the actual port is located. It was much smaller compared to Nicosia or Famagusta and even de Bruyn wrote about this: "Larnica is, as I have said, just a moderate-sized village" (Cobham, 1908 , p. 240). The fate of Larnaca changed when Famagusta was closed off to all foreigners. As a result, the main port Famagusta was replaced by Larnaca as the new commercial trade centre of the island especially due to its connection with the capital city, Nicosia. Larnaca became an international town with foreign merchants and consuls and continual visits from merchant ships (Gunnis, 1947, p.106). Mariti wrote that

The port of the Salines in the south of the island is the general anchorage for vessels of every nation, not only because it is the best to be found in all the kingdom of Cyprus, but also because it is the nearest to Larnaca, the city which has the greatest trade in all island (Mariti, 1909, p.17).

In Larnaca, the mark of the war wasn't as obvious as it was in other cities. Unlike Famagusta or Nicosia, Larnaca does not have fortifications. It has a small fort near the harbour. This building was a small fortification from the fourteenth century that was turned into a castle for the protection of the harbour during the Ottoman era (Bağışkan, 2018, p. 577). After the conquest, the church dedicated to the Holy Cross was converted to Cami-I Kebir (Ulu Cami) as the only mosque in Larnaca (Mariti, 1909, pp.26-28). In addition, several tekke (dervish lodges) were built during this era. Another important structure is St. Lazarus church, the place of Lazarus' tomb, which was turned into a mosque but later given back to the Christian community (Jeffery, 1918, pp.167-170). Regarding the inner city, houses were mostly one-storey buildings with gardens inside. Larnaca was also the residence of several consuls; their two-storey houses coloured the view of the city (Mariti, 1909, p.31). One significant project for Larnaca was bringing water to the town. Between the years 1746 and 1748, Ebu Bekir Pasha built fountains, bridges, wells, and most importantly, an aqueduct to carry water from Arpera (Bağışkan, 2018, p.581).

\section{The Travellers}

Cornelis de Bruyn was a Dutch traveller and artist who started one of his two large tours in 1674 in The Hague and travelled to the East until returning to The Hague in 1693. In 1683 he visited Cyprus and created a profile view of Famagusta and published it in Reizen van Cornelis de Bruyn door de vermaardste Deelen van Klein Asia. English and French editions of his travel accounts were also published in 1702 and 1714, respectively. In his accounts, he wrote his observations on many cities of the island and he also described the natives, clothes, culture, architecture, etc. (Cobham, 1908, pp.236-244). ${ }^{1}$

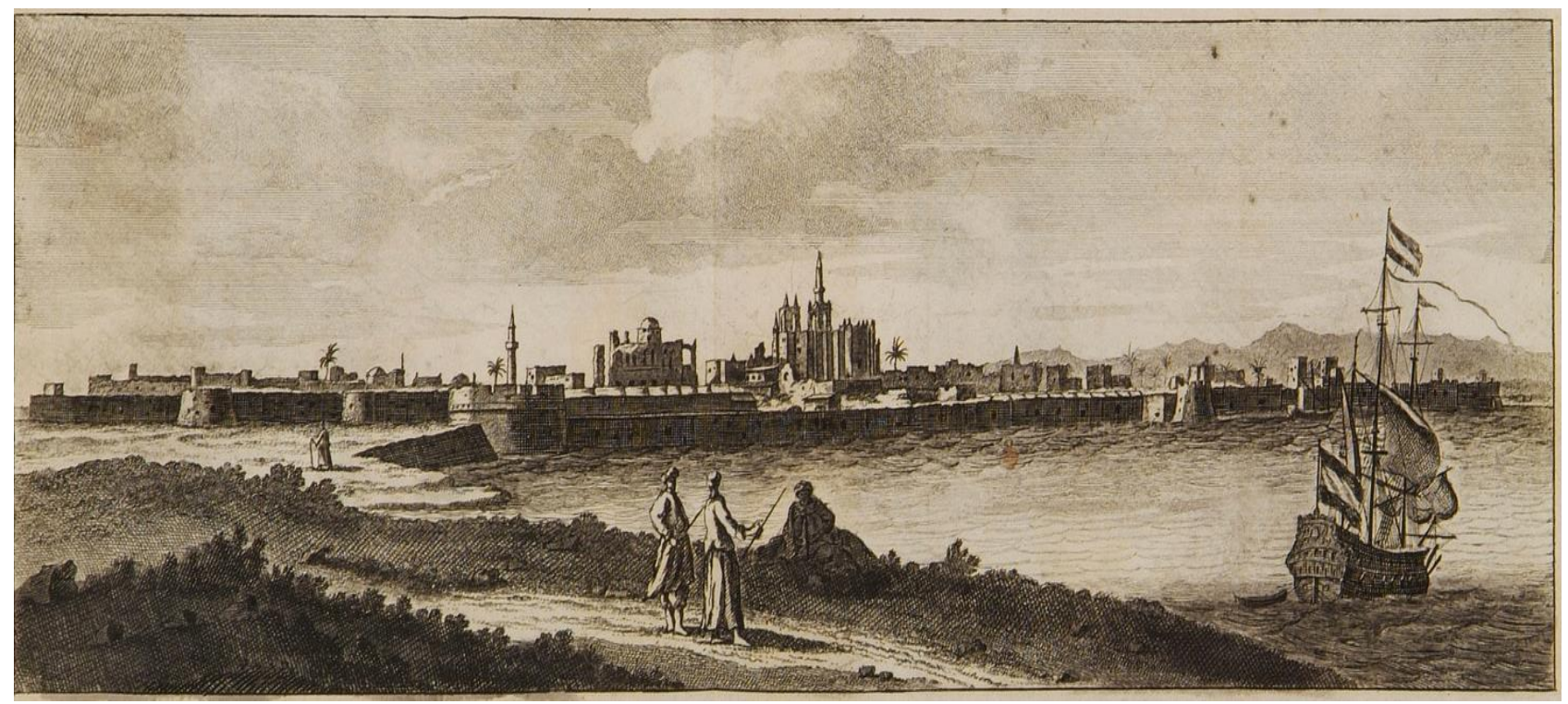

Figure 1. Cornelis de Bruyn, "Famagusta", in Voyage au Levant, c'est-à-dire, dans les principaux endroits de l'Asie Mineure, dans les isles de Chio, Rhodes, \& Chypre \&c. De même que dans les plus considerables villes d'Egypte, de Syrie, et de la Terre Sainte; enrichi de plus de deux cens tailles-douces, où sont représentées les plus célèbres villes, pais, bourgs, \& autres choses dignes de remarque, le tout dessiné d'après nature, Paris, Guillaume Cavelier, 1714. Hellenic Library - Alexander S. Onassis Public Benefit Foundation. Source: Aikaterini Laskaridis Foundation Library, Athens.

\footnotetext{
${ }^{1}$ C. D. Cobham edited and translated various accounts about Cyprus in Exerpta Cypria. In the book Cornelis de Bruyn's name was given as Cornelis Van Bruyn whereas in the Dutch edition of his travels from 1698 the name Cornelis de Bruyn was used.
} 
In his drawing of Famagusta (Fig. 1), he depicted the city from outside the walls since he was not able to enter it. He wrote;

In the afternoon I went with two Greeks to see the outside of Famagusta, but as I got too near the Turks shouted to me from the walls to retire. I had to obey, and turning down to the seashore sat down on a little eminence to sketch the city as carefully as possible (Cobham, 1908, p.236).

The city was depicted in the background and in the foreground, he added the harbour and some natives, as well as a Dutch ship. Even though foreign merchants preferred the port of Larnaca, especially with the privilege by the Ottoman Empire, the port of Famagusta was still used by a limited number of ships. The harbour's condition was getting worse though, and could only be used by small vessels (Arkan, 2017, p.39).

On the illustration, the city's fortifications are the main identification point of Famagusta as he describes it in his account (Cobham, 1908, p.236). The St. Nicholas Cathedral is dominant in the middle of the image as the biggest construction within the city. The design of the cathedral can be seen in the drawing with the addition of a minaret. His observation about the Cathedral, which was referred to as S. Sophia, reads: "The mosque called S. Sophia seems very fine: it must indeed be as grand as its reputation. The pointed tower which crowns the building is highly ornamental" (Cobham, 1908, p.236). Next to it, the Church of St. George of the Greeks can be seen with its dome and buttresses, as well as a few lower private structures, minarets and palm trees form the inner city. As it is a profile image, the structure and layout of the city cannot be observed. As far as he could see the city from a distance, he was able to depict the Ottoman Famagusta.

Vasily Grigorovitch Barsky or Vasyl Hryhorovyč Bars'kyj of Kiev was a Russian Orthodox monk who travelled to Cyprus in the eighteenth century. He was a traveller, author and artist who was interested in the religious life of the island, especially in the monasteries. He visited the island several times, in 1726, 1727 and 1730. During his last visit, he stayed for almost two years between 1734 and 1736. While he was teaching Latin in Nicosia after the earthquake in 1735 , he decided to cut short his teaching and ended up travelling around various monasteries of the island. He wrote primarily about monasteries but also about towns, people and the island in general. He also made various drawings ${ }^{2}$ of monasteries and towns, such as Famagusta, Nicosia and Larnaca (Grishin, 1996).

During his third visit, he wrote about the city and harbour of Famagusta:
The town is encircled by a strong wall, with cannons mounted on top, as on Rhodes, and appears attractive to the eye and is well defended against enemies. In it, there are old buildings and beautiful churches going back to ancient times, some of which are now empty, and others have been converted into Turkish mosques (Grishin, 1996, p. 23).

In the pen and ink drawing of Famagusta (Fig. 2), he depicts the fortification, harbour and inner city. At the centre, the Cathedral was depicted in detail and it was oversized compared to other structures. Its Gothic architecture can be seen with details of its buttresses, two towers and oval shape with the minaret which was added after the Ottomans converted it into a mosque. Across from the Cathedral is another building that stands out from the others because of its high walls, which is probably the Palace. The rest of the city is filled with private and domed buildings and minarets/mosques. At the front, we see the small harbour bustling with ships in its inner and outer parts.

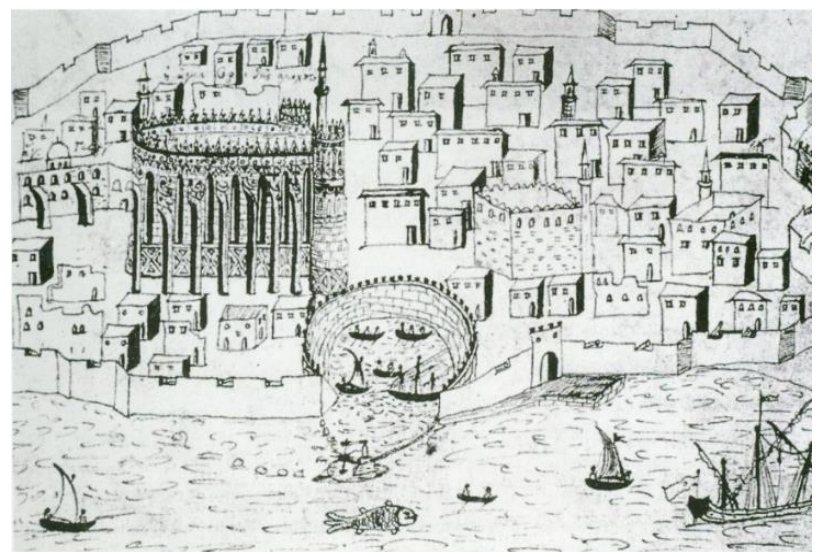

Figure 2. Vasily Grigorovich Barsky, "Famagusta", 1730, MS fol. 238r, Akademija Nauk, Kiev. Source: Grishin, A. D. (Trans.) (1996). A Pilgrim's Account of Cyprus: Barskyi's Travels in Cyprus, Sources for the History of Cyprus, Volume 3, New York: Greece and Cyprus Research Center.

Besides his depiction of Famagusta, Barsky also made an illustration of Nicosia (Fig. 3). In his accounts, he mentions the city, the Cathedral and fortification as the

...most important and largest town on the island of Cyprus...The town was once very beautiful, when the Venetians ruled over it...the great and very beautiful church of Saint Sophia, which is constructed of finely dressed stone, and which can be seen from a distance from outside the town. The Turks have now transformed it into their own mosque... The town is surrounded by a strong and attractive wall; but inside, the buildings are not particularly pleasing, but because of the numerous fruit trees the town is very beautiful, and from a distance appears as a garden (Grishin, 1996, pp.14-15).

\footnotetext{
${ }^{2}$ His manuscript is in the archive of the Akademija Nauk of Kiev v, No:1052. After Barsky's death, in 1778 V. G. Ruban edited an abridged edition of his manuscript and later in 1885 an improved edition was published by Nikolai Barsukov.
} 


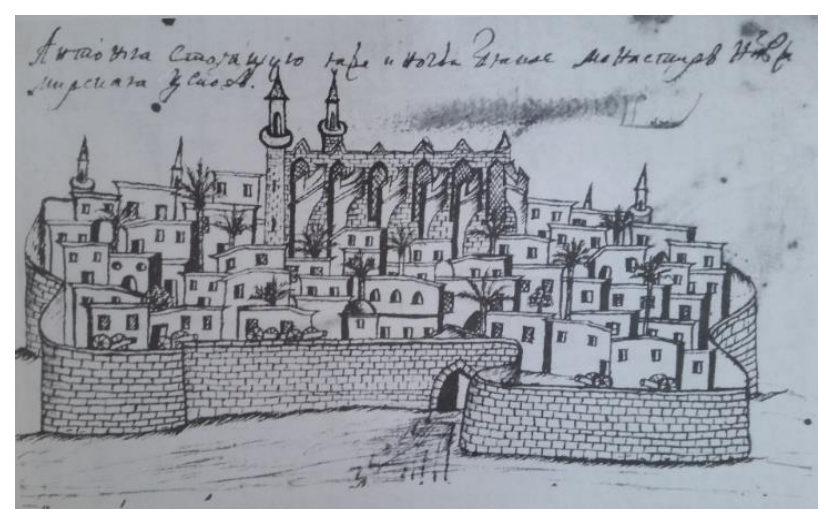

Figure 3. Vasily Grigorovich Barsky, "Leukosia", 1727, MS fol. 173r, Akademija Nauk, Kiev. Source: Grishin, A. D. (Trans.) (1996). A Pilgrim's Account of Cyprus: Barskyi's Travels in Cyprus, Sources for the History of Cyprus, Volume 3, New York: Greece and Cyprus Research Center.

The Cathedral takes up a large portion of his drawings and he added minarets with crescents to this Gothic building. He praised the Cathedral's outer appearance while not being able to comment on the inside as he was not allowed to enter the place (Grishin, 1996, p.14). Barsky also mentioned the destruction of the Venetian architecture in the hands of the Turks and the ruins within the city and complained about the abandonment of some churches and the high taxes. He wrote that "When God allowed the Turks through war to seize the town into their own hands, they devastated all of it and destroyed the houses and the beautiful palaces down to their foundations" (Grishin,
1996, p.14). Beside the minaret of St. Sophia, at the back four other minarets can be observed, showing and symbolizing the Muslim rule of the city. Private houses surround the Cathedral, one- or two-storey buildings, and palm trees echo the writings of travellers who described the city's appearance turning oriental as well as the famous gardens which appear in the writings and on the drawings.

Another drawing by Barsky depicts the port city Larnaca and the harbour Salines together (Fig. 4). The drawing includes the city itself in the background and the marina in the foreground. In the port, the fort with cannons was depicted. In the lower part, a minaret defines the Muslims and the Ottoman rule; behind the port is Ulu Camii. Behind the fort to the right, St. Lazarus Church is depicted where he mentions a palace in his writings (Grishin, 1996, p.15). In the background, you see the Stavrovouni monastery, which was often mentioned in the writings because it is where a piece of the Holy Cross is kept. The monastery is located at the peak of the mountain close to Larnaca (Jeffery, 1918, pp.189-193), which is why on the drawing it dominates the whole hill. Two larger houses were drawn and named as the British and French consuls' houses with flags. We also get a glimpse of the harbour with the depiction of the top part of the mast of a ship. With the details such as palm trees, inhabitants, ships, churches and mosques and varied structures within the city, the drawing provides an appearance of a multicultural city to the audience.

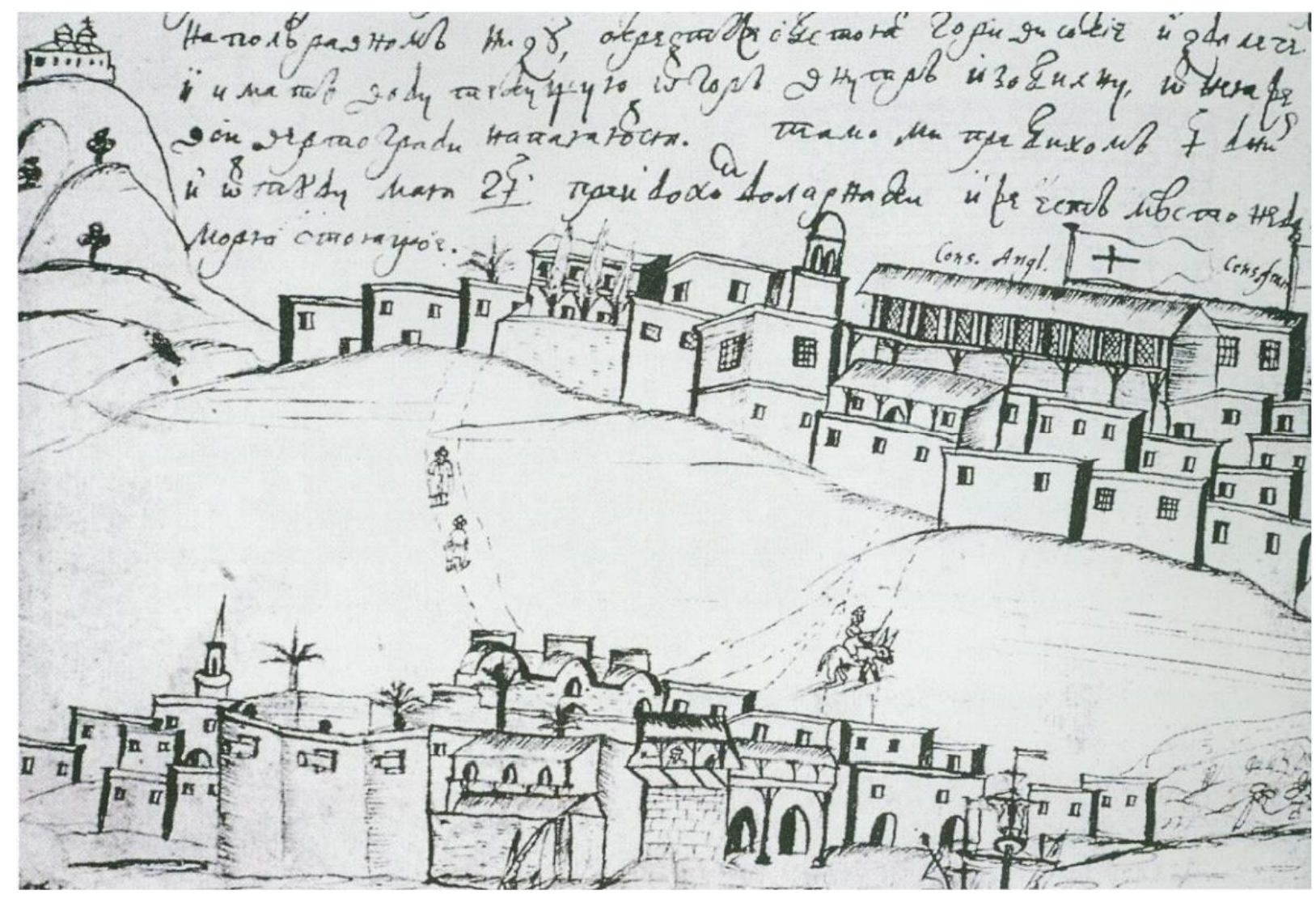

Figure 4. Vasily Grigorovich Barsky, "Larnaca and Alikas", 1727, MS fol. 173v, Akademija Nauk, Kiev. Source: Grishin, A. D. (Trans.) (1996). A Pilgrim's Account of Cyprus: Barskyi's Travels in Cyprus, Sources for the History of Cyprus, Volume 3, New York: Greece and Cyprus Research Center. 
Although these drawings of Famagusta, Nicosia and Larnaca are not accurate representations, they are able to give information about the Ottoman rule and changes that happened in the cities while emphasizing their significant features, both Christian architecture as well as Islamic additions.

Physician and writer Olfert Dapper also wrote about Cyprus in his travel books, which provide information on history, geography, economy, politics, medicine, social life, and customs, etc. Since he never travelled to the locations he wrote about, his work relied on other printed sources.

Figure 5 shows a copper engraving map of Famagusta from his book Naukeurige Beschryving der Eilanden in de Archipel der Middlelantsche Zee in 1688. It is a bird's eye view of the city and depicts the inner city with buildings, gardens and roads, but without giving names of specific buildings or churches. Since the depiction of the citadel is inaccurate, the map is probably based on a wooden model of the city from the sixteenth century in Venice (Arkan, 2017, p.44). As such, the fortifications shown are mostly accurate but the image is dated. Dapper reported about the depopulation and that the Christians could no longer live in the inner city but had to move to Varosha (Dapper, 1688, p. 29). So, Varosha is represented as being fertile with gardens, which gives updated information about the outside of the city. However, the absence of the main buildings creates an unreliable image of Famagusta, not depicting the Ottoman rule or cultural structure of the city.

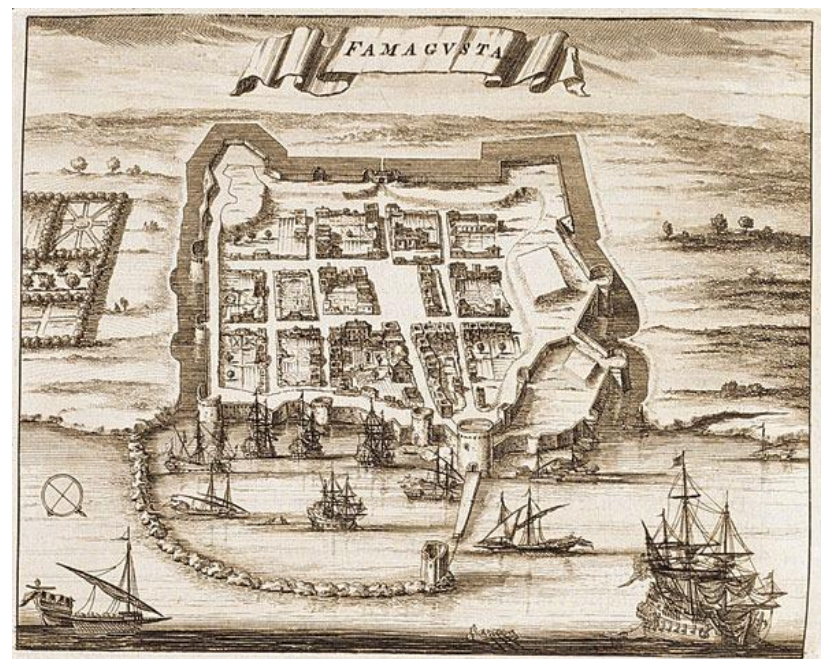

Figure 5. Olfert Dapper, "Famagusta" in Naukeurige Beschryving der Eilanden in de Archipel der Middelantsche Zee, en ontrent dezelve, gelegen: Waer onder de voornaemste Cyprus, Rhodes, Kandien, Samos, Scio, Negroponte, Lemnos, Paros, Delos, Patmos, en andere, in groten getale..., Amsterdam, Wolfgangh, Waesbergen, Boom, Someren, Goethals, 1688. Hellenic Library - Alexander S. Onassis Public Benefit Foundation. Source: Aikaterini Laskaridis Foundation Library.

The depiction of Larnaca in Figure 6 is from the same book as that of Famagusta and the drawing shows the appearance of the city from the sea, as a small settlement. At the front are two large structures: the fort and St.
Lazarus church. With this image, the audience gets an idea of the landscape with the palm trees and mountains surrounding the city. The majority of the drawing is taken up by the ships in the foreground. As the major harbour of this century and home of various foreign consuls, the harbour had many visitors especially from Europe and their ships are represented on the map. Two-storey buildings were illustrated, which were the Consul's houses mentioned by travellers at various times. The images do not reflect Ottoman Cyprus except for providing several updated circumstances.

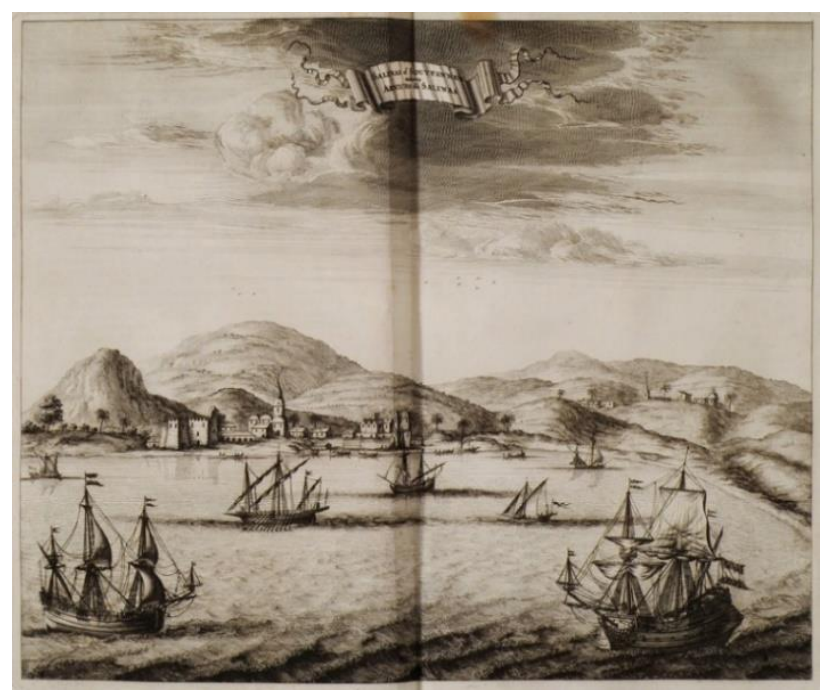

Figure 6. Olfert Dapper, "Salinas of Southpannen, Anders Arnicho di Salinas ou Les Salines", in Naukeurige Beschryving der Eilanden in de Archipel der Middelantsche Zee, en ontrent dezelve, gelegen: Waer onder de voornaemste Cyprus, Rhodes, Kandien, Samos, Scio, Negroponte, Lemnos, Paros, Delos, Patmos, en andere, in groten getale..., Amsterdam, Wolfgangh, Waesbergen, Boom, Someren, Goethals, 1688. Hellenic Library - Alexander S. Onassis Public Benefit Foundation. Source: Aikaterini Laskaridis Foundation Library.

Another traveller who visited Cyprus was Alexander Drummond who was an English Consul in Aleppo between 1754-56. He visited Cyprus from March to May 1745 and for a second time in April 1750. His Travels through Different Cities of Germany, Italy, Greece, and Several Parts of Asia... was published in 1754 and contains letters addressed to his brother and friends. In Letters VI, VII, VIII, and XIII he mentioned the island and wrote about various subjects including its history, administration, trade, etc... as well as its cities, including Famagusta, Nicosia and Larnaca.

In his writings, he pointed out that there is not much to see in these locations and the disregard of the Ottomans towards them. Drummond (1754) wrote about Famagusta's strong fortifications, adding that "As this is all I have to say about Famagusta, you will readily own it was not worth the fatigue I underwent in going to see it..." (p.139). About Nicosia, he wrote

The city was well fortified by the Venetians, according to the manner of those times; but all is gone to ruin 
through the supine negligence and blind security of the Turks. The place is round and maybe about three miles in circumference, but not well inhabited; a circumstance to which it owes its very pleasant and beautiful appearance...St. Sophia, now converted to a Turkish mosque, is the only fabric which remains entire, and is of tolerable gothic work... (Drummond, 1754, p.172).

Even though in his accounts all three cities were included, the only map he drew was an engraved plan of the bay of Larnaca in Letter VIII, which shows the coastline of Larnaca from Cape Greco to Chitty. Again he was not impressed by the town (Drummond, 1754, p.140).

On the chart (Fig. 7), he pointed out a few important settlements, including Larnaca, Arpera and Salines. These were illustrated with architectural structures surrounded by trees, except for Salines which was depicted as a fort on the coastline. He also drew Arpera, where aqueducts carry water from its river to Larnaca (Jeffery, 1918, p.185). It usually does not appear on maps but is important for Larnaca as its new water source (Drummond, 1754, p.251).

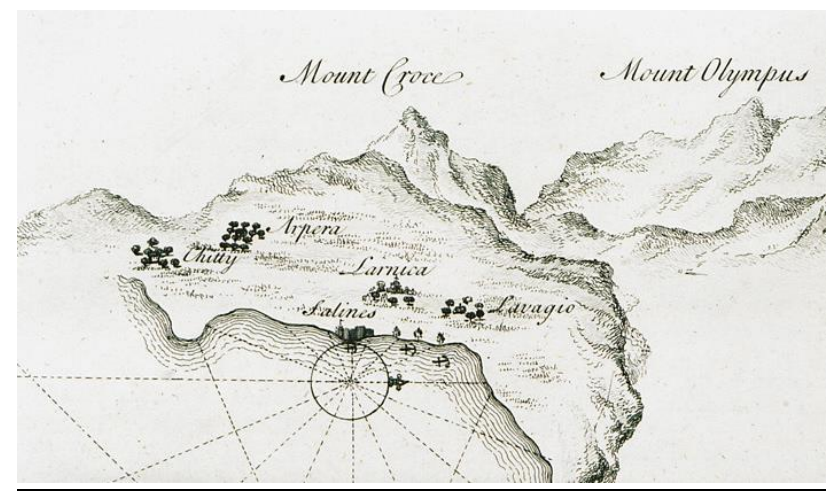

Figure 7. Detail from Alexander Drummond's "Salines Bay", in Travels through different Cities of Germany, Italy, Greece, and several parts of Asia, as far as the banks of the Euphrates: In a Series of Letters. Containing, an account of what is most remarkable in their present state, as well as in their monuments of antiquity, London, W. Strahan for the author, MDCCLIV [=1754]. Source: Aikaterini Laskaridis Foundation Library, Athens.

Because this is a chart, the depiction of the cities is limited, not showing much detail. There are examples of the usage of symbols like minarets and crescents or mosques to distinguish the Ottoman cities on other charts from this era; one example is Joseph Roux's chart of Larnaca and Famagusta (Arkan, 2017, p.88; Fig.8), however, on Drummond's images there are no symbols or other indications of the Ottoman rule.

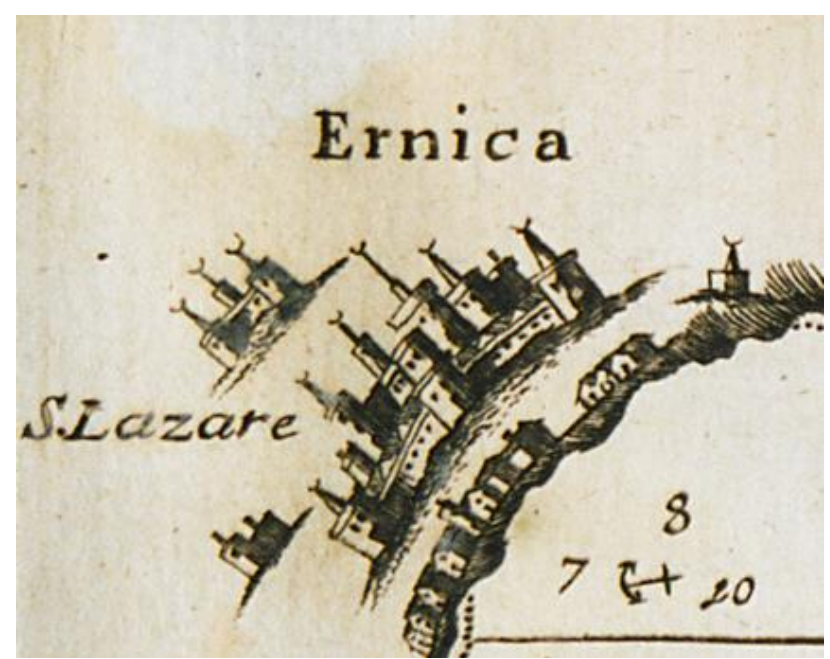

Figure 8: Detail from Joseph Roux's "Cipre"-"Ernica""Famagouste", in Recueil des principaux plans, des ports, et rades de la Méditerranée dont 40 ont été derniérement publiés par Jean Joseph Allezard ancien Capitaine de Marine et plusieurs des autres corrigés, chez Yves Gravier Libraire sous la Loge de Banchi, 1804. Source: Aikaterini Laskaridis Foundation Library.

Lastly, Henry de Beauvau, a diplomat and army officer, visited the island while he was escorting the French Ambassador on his voyage to Constantinople in 1604 (Cobham, 1908, p.209). In his account, he mentioned the cities briefly, but his descriptions are not detailed nor informative as he only provides their location and mentions a few features. He wrote that

Its chief towns are Nicosia and Famagusta, the first is about thirty miles from the coast, almost round, and fortified by good bastions; it is the residence of the Pasha of the island, and of the Consul of the Franks. The other is much stronger, and has a port not far away, but it is not always that any but small vessels can enter it: it is the same with all the ports of the island, with the exception of certain roadsteads, such as you find at I'Ampso and the Salines (Cobham, 1908, p.209).

The maps of Nicosia and Famagusta are from the second edition of the French booklet which covers his journey in the Levant (Arkan, 2017, p.72). The depictions of both cities were based on older maps from the sixteenth century: Giovanni Camocio's map of Nicosia from 1571 without the siege and Braun and Hogenberg's map of Famagusta from 1572. ${ }^{3}$ During the Ottoman-Venetian war, the maps of Famagusta and Nicosia were popular, and several maps with or without a depiction of the siege were produced. During the Ottoman era, the map production of the cities was decreased, the majority of the maps from later centuries were based on these old maps (Arkan, 2018).

On the maps of Nicosia and Famagusta (Fig. 9,10), a host of conventional buildings can be seen inside the cities. The

\footnotetext{
${ }^{3}$ Giovanni Francesco Camocio's map "Nicosia” was published in Isole famose porti, fortezze... In Venetia alla libraria del segno di S. Marco, in ca. 1575, and Georg Braun and Frans Hogenberg's map "Calaris"/ "Malta"/ "Rhodus"/ "Famagusta" was published in 1572 in Civitates Orbis Terranum (Arkan, 2017, p.63; 32).
} 
Cathedrals stand out in their midst. For Famagusta, the palace opposite the Cathedral is another significant building (Fig.10). There are several towers that indicate smaller churches that are spread out inside the walled cities, but they cannot be identified. Besides these structures, the rest of the space is filled with private houses without any specific design. For both images, the fortifications became the identifying features of each city.

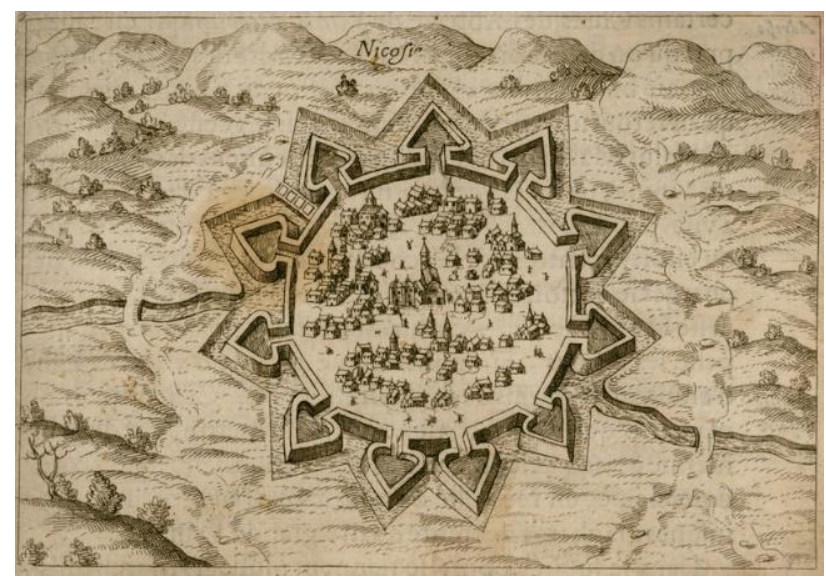

Figure 9: Henry de Beauvau, "Nicosie" in Relation Iournalière du Voyage du Levant faict \& descrit ... Reveu augmenté et enrichy par l'Autheur..., Nancy, Jacob Garnich, 1615. Hellenic Library - Alexander S. Onassis Public Benefit Foundation. Source: Aikaterini Laskaridis Foundation Library, Athens.

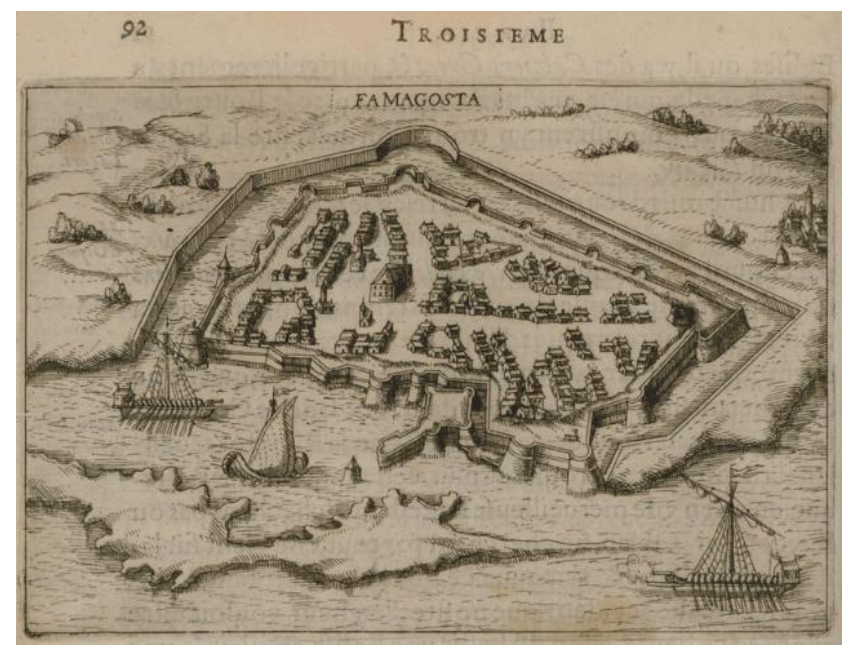

Figure 10: Henry de Beauvau, "Famagusta" in Relation Iournalière du Voyage du Levant faict \& descrit ... Reveu augmenté et enrichy par l'Autheur.... Nancy, Jacob Garnich, 1615. Hellenic Library - Alexander S. Onassis Public Benefit Foundation. Source: Aikaterini Laskaridis Foundation Library, Athens.

Beauvau only used information available from the previous century, so his images are essentially replicas of sixteenth-century maps of Nicosia and Famagusta. The maps do not give any additional information about the cities, the Ottoman rule or the transformation of the cities during this era.

\section{Discussion and Conclusion}

An artistic image of a city can be defined with identity, structure and meaning (Lynch, 1960). In the mentioned writings and their accompanying images, particular landmarks were used to define the cities. For Nicosia and Famagusta, their fortifications and cathedrals were used as identifiers. Nicosia and Famagusta were surrounded by walls that were mentioned and praised by the travellers for their strong and impassable aspects. After all, Famagusta had withstood the Ottoman siege for almost a year (Gunnis, 1947, p.85). The cathedrals played an important role for Famagusta and Nicosia as the most eye-catching monuments within their walls. Especially for Famagusta, when the travellers were not able to visit the city, the cathedral is the one building that they can see and identify from outside the walls. The harbour was another significant feature to define the two main port cities, Famagusta and Larnaca. For Larnaca, besides its harbour, St. Lazarus church, the fort and consul houses were noticeable for the travellers and therefore featured in their writings and images. Creating these images is a two-way process between observer and observed to strengthen the imaged symbolic devices used (Lynch, 1960, p.11). These landmarks are significant for the history of Cyprus, they are most attention-grabbing and easy to recognize by their audience.

When these Venetian/Christian cities were transformed to Ottoman/Muslim cities major changes occurred that can be seen all over the cities. The conversions started with the establishment of mosques and their minarets which were structures visible from both sea and land (Bierman, 1991). Ottomanization was explained by Irene Bierman (1991) as, "the Ottoman building program reinforced the political and religious values of the Ottoman Muslim hierarchy and the political conditions at the capital and throughout the empire" (p.53). The situation was valid for all three cities; the cathedrals and churches were converted to mosques and bell towers were turned into minarets. So the profile and silhouette of the cities were changed from Christian to Muslim. In all accounts the current living conditions and transformation of the cities are reported, sometimes in detail, sometimes not, but all present the idea to their audience.

These changing characteristics of the cities were not depicted in all images. Drummond who wrote about the island in detail depicted only Larnaca in a nautical chart, which as a medium did not show features of the city itself. Dapper who didn't travel to Cyprus and compiled his account from other printed sources, was only partially able to capture the changing situation of the Ottoman Famagusta. Since he used other sources, it is only fair to say that his depiction is not accurate but a repetition of Beauvau's maps which again do not give up-to-date 
information or show the current situation since Beauvau only used sixteenth-century maps as a source.

On the other hand, Barsky who stayed in Cyprus for a longer period depicted the three cities in his sketches which represented the history and the transformed cities while emphasizing the Cathedrals, its Christian past, additions of Ottoman features and its new identity. De Bruyn who depicted Famagusta was able to draw the city with its new additions like minarets. However, the inside of the city was a mystery to him and his audience. In the case of Famagusta, the depiction of the inner city was hard and for a time impossible due to restrictions. However, that didn't stop him from drawing Ottoman Famagusta.

A mosque complex is a significant part of Ottomanization but also other architectural structures like mescit, tekke, cemeteries, bathhouses etc., are important parts as they turn the urban spaces "to support Ottoman Muslim activities" (Bierman, 1991, p.53). In the writings, the information on Islamic architecture that appears within the cities was limited. The description of the oriental Cypriot cities includes palm trees, narrow streets and houses with cumba, but the public areas and public buildings that serve Islamic culture as part of the cities' identity were omitted.

The travellers wrote about what they were familiar with, rather than mentioning the unique characteristics of the Ottoman city. The eye-witnesses were travellers who were visiting the once Christian lands. As Lynch (1960) points out, the meaning of representation is linked to the observer and his relation with the observed (p.8). The images only showed Cyprus' condition from the outside and what the cities meant to an outsider. In addition, the depictions were made for an audience unfamiliar with Cyprus where the only information received was from the depictions or the texts. The analysis points out that the images of the cities were descriptive representations and that only a few defining architectural features were used to represent them, just enough to be recognized by their audience and to define their transformation. Travellers didn't underline the Ottoman features of the cities.

The travellers' experiences were mixed when it came to Cyprus; usually, they found the island beautiful and wrote about its beauty and richness, praising its water and wheat (Cobham, 1908, p.243; Grishin, 1996, p.12). On the other hand, the travellers often wrote about the neglect and abandonment of the cities by the Ottoman Empire. Whether they were giving their opinion on the Ottoman administration or describing the cities, they were usually not pleased with the current situation of the island. These travel writings reflected the changes of Cyprus as well as the shifting image of the Ottoman Empire in the eyes of travellers. Victoria Thomson (2019) wrote, "Urban travel writing is thus highly attentive to the ways in which the spaces and structures of cities serve as metaphors for larger cultural, political, and social concerns and as a means for reflecting on the self" (p. 301). De Bruyn wrote about his experience

The Turks guard the city so jealously that no stranger is allowed to set foot in it... Even the Greek inhabitants of the island dare not approach the ramparts, or if caught they run the risk of being forced to become Musalmans (Cobham, 1908, p.236).

At a time when the threat of the Ottoman Empire was a pressing issue in Europe, it was understandable he expressed his fear towards the Ottomans. ${ }^{4}$ As MacLean (2007) wrote, "Fear never entirely disappears from these travellers' accounts; it simply becomes part of the fascination" (p.95). Almost a century after de Bruyn, Drummond (1754) wrote: "the natives were always remarkably effeminate and lazy" (p.133). He continued about the natural resources of the island "I am fully persuaded, that, if it were in the hands of the English, or Dutch, they would make such advantageous use of the springs, rivulets, and winter rains..." (p.133). Travellers' perceptions of the Ottoman Empire had changed; fear was replaced with condescension as the image of the Ottomans changed through time (Lewis, 1993).

The opinions and experiences with the Ottomans were not highly positive. Perhaps, this attitude suits the traditional image of the Ottoman Empire in the eyes of the outsiders while these representations conformed to their audience's interests and expectations.

\section{References}

Arkan, M. S. (2017). The Urban Cartography of Cyprus: Between the 16th and 20th Centuries, (Doctoral dissertation, Eötvös Loránd University, Hungary). Retrieved from http://lazarus.elte.hu/hun/doktoran/arkan/arkandissertation.pdf

Arkan, M. S. (2018). Invariable Image of Cyprus: Reproduction of Siege Maps of Nicosia and Famagusta. In: M. Altić, I. Demhardt, S. Vervust (Eds.) Dissemination of Cartographic Knowledge. Lecture Notes in Geoinformation and Cartography, Springer, Cham, pp. 41-52.

Bağışkan, T. (2018). Kıbrıs'ın Geçmişine yolculuk, Lefkoşa, Kıbrıs türk yazarlar birliği Yayını.

Bierman, I. A. (1991). The Ottomanization of Crete. In I. A. Bierman \& R. A. Abou-El-Haj, D. Preziosi, (Eds.), The Ottoman City and Its Parts Urban Structure and Social Order, New York, Aristide D. Caratzas, pp.5375.

\footnotetext{
${ }^{4}$ In the English translation, the phrase "being forced to become Musalmans" was translated as "being forced to turn Turks" (Le Brun, 1702, p.266).
} 
Cobham, C. D. (Ed., Trans.) (1908). Excerpta Cypria: Materials for a history of Cyprus: with an appendix on the bibliography of Cyprus. New York: Kraus Reprint.

Dapper, O. (1688). Naukeurige beschryving der Eilanden, in de Archipel der Middelantsche Zee, en omtrent dezelve, gelegen: waer onder de voornaemste Cyprus, Rhodus, Kandien, Samos, Scio, Negroponte, Amsterdam.

Drummond, A. (1754). Travels Through Different Cities of Germany, Italy, Greece, And Several Parts Of Asia, As Far As The Banks Of The Euphrates: In a Series of Letters. Containing, An Account of what is most remarkable in their Present State, As well as in their Monuments Of Antiquity. By Alexander Drummond, Esq; His Majesty's Consul at Aleppo. London, William Strahan for the author.

Gazioğlu, A. C. (2000). Kıbrıs'ta Türkler (1570-1878): 308 yıllık Türk dönemine bir bakış. (2 $2^{\text {nd }}$ ed.). Lefkoşa: Kıbrıs Araştırma ve Yayın Merkezi (CYREP).

Grishin, A. D. (Trans.) (1996). A Pilgrim's Account of Cyprus: Barskyi's Travels in Cyprus, Sources for the History of Cyprus, Volume 3. New York, Greece and Cyprus Research Center.

Gunnis, R. (1947). Historic Cyprus: A guide to its town and villages, monasteries and castles. London, Methuen \& Co. Ltd.

Gürkan, H. M. (2006). Dünkü ve bugünkü Lefkoşa. (3 ${ }^{\text {rd }}$ ed.) Lefkoşa, Galeri kültür yayınları.

Hill, G. (1948). A History of Cyprus. Volume 3: The Frankish Period, 1432-1571. Cambridge, Cambridge University Press.

Jeffery, G. F. S. A. (1918). A description of the historic monuments of Cyprus. Nicosia, William James Archer, Government Printing Office.

Le Brun, C. (1702). A Voyage to the Levant: Or travels in the principal parts of Asia Minor. London: Jacob Tonson.

Leitch, S. (2019). Visual Images in Travel Writing. In: N. Das \& T. Youngs (Eds.), The Cambridge History of Travel Writing, Cambridge, Cambridge University Press, pp.456-73.

Lewis, B. (1993). Islam and the West. New York, Oxford, Oxford University Press.

Luke, H. (1969). Cyprus under the Turks: 1571-1878. (Rev. ed.) London, C. Hurst \& Company.

Lynch, K. (1960). The image of the city. Cambridge, Massachusetts, The MIT Press.

Mariti, G. (1909). Travels in the Island of Cyprus: With Contemporary Accounts of the Siege of Nicosia and Famagusta. C. D. Cobham (Trans.), Cambridge, Cambridge University Press.

MacLean, G. (2007). Looking East: English Writing and the Ottoman Empire before 1800. New York, Palgrave Macmillan.

MacLean, G. (2019). Early Modern Travel Writing (1): Print and Early Modern European Travel Writing. In: N. Das \& T. Youngs (Eds.), The Cambridge History of Travel Writing, Cambridge, Cambridge University Press, pp.456-473.
Preziosi, D. (1991). Introduction: The Mechanisms of Urban Meaning. In: I. A. Bierman \& R. A. Abou-ElHaj, D. Preziosi, (Eds.), The Ottoman City and Its Parts Urban Structure and Social Order, New York, Aristide D. Caratzas, pp.3-11.

Rüstem, Ü. (2019). From Auspicious Ornament to State Symbol: The Crescent Moon in Ottoman Art and Architecture. In C. Gruber (Ed.). The Moon: A Voyage through Time, Canada, Aga Khan Museum, pp.45-55.

Thompson, V. (2019). Travel and the City. In N. Das \& T. Youngs (Eds.), The Cambridge History of Travel Writing, Cambridge, Cambridge University Press, pp.456-73.

Uluca, E. (2006). Gazimağusa kaleiçi’nin Tarihsel Süreç içindeki Kentsel Gelişimi ve Değişimi (Doctoral dissertation, İstanbul Technical University, İstanbul). Retrieved from https://polen.itu.edu.tr/handle/11527/4213 